\title{
TWO HARMALA ALKALOIDS FROM Lawsonia inermis SEEDS
}

\author{
P. Philip Jacob and A. Mary Saral*
}

UDC 547.945

Lawsonia inermis L. (Lithraceae) is commonly called henna. The dye derived from green leaves of henna is used to decorate the body with intricate designs, and the principal coloring matter is lawsone, 2-hydroxy-1,4-naphthoquinone. Phytochemical studies on henna seeds revealed the presence of behenic acid, arachidic acid, stearic acid, linoleic acid, palmitic acid, lawnermis acid, and its methyl ester [1, 2].

In the present study we report the isolation of harmine and harmaline from the ethanol extract of henna seeds. Henna mature seeds (plucked after drying) were collected from Naatura Farms, Odugathur, Vellore District. About 300 grams of seed powder was extracted with one liter ethanol after defatting with petroleum ether. The residue of seeds after ethanol extraction was used for further extraction with water to yield an aqueous extract.

The ethanol extract on rinsing with chloroform yielded a yellow colored mass weighing about $205 \mathrm{mg}$. This was chromatographed over silica gel using chloroform-methanol as eluent. Initially the column was run using chloroform. We have collected 140 fractions there was no blue coloration seen from 1-119. Fractions from 120 showed a single blue colored spot on TLC under UV, which on evaporation yielded $66.2 \mathrm{mg}$ of white crystalline powder (compound 1). The solvent ratio was gradually increased to 9.5:0.5, and a florescent compound was obtained, which after collection and evaporation yielded $30 \mathrm{mg}$ of yellowish green colored amorphous powder (compound 2). Compounds 1 and $\mathbf{2}$ were identified using UV, APIES MASS, ${ }^{1} \mathrm{H}$ NMR, ${ }^{13} \mathrm{C}$ NMR, and 2D NMR spectral data and by comparing them with literature data.

Compound 1, $\mathrm{C}_{13} \mathrm{H}_{12} \mathrm{~N}_{2} \mathrm{O}, \operatorname{mp} 264 \pm 2{ }^{\circ} \mathrm{C}, m / z 213.2[\mathrm{M}+\mathrm{H}]^{+}$, was identified from its UV, ${ }^{1} \mathrm{H}$, and ${ }^{13} \mathrm{C}$ NMR spectra $[3,4]$ as harmine.

Compound 2, $\mathrm{C}_{13} \mathrm{H}_{14} \mathrm{~N}_{2} \mathrm{O}, \mathrm{mp} 238^{\circ} \mathrm{C}, \mathrm{m} / z 215.3[\mathrm{M}+\mathrm{H}]^{+}$, was identified from its $\mathrm{UV},{ }^{1} \mathrm{H}$ and ${ }^{13} \mathrm{C}$ NMR spectra $[3,4]$ as harmaline.

The obtained ethanol and aqueous extracts reduced the diazepam-induced sleeping time of mice, supporting the use of henna seeds as a stimulant by the village folks of Vellore District. Harmine and harmaline were isolated for the first time from Lawsonia inermis.

\section{ACKNOWLEDGMENT}

We thank the Department of Science and Technology for providing the INSPIRE fellowship (to the first author, INSPIRE Fellow code - IF 110262).

\section{REFERENCES}

1. S. R. Agarwal, S. N. Ghatak, and D. R. Dhingra, Indian Oil Soap J., 25, 145 (1959).

2. G. Handa, A. Kapil, S. Sharma, and J. Singh, Indian J. Chem., 36B, 252 (1997).

3. A. G. Eshimbetov and T. S. Tulyaganov, Spectrochim. Acta A, 67, 1139 (2007).

4. B. Hicham, M. C. Carmen, K. Abdelouahed, M. Hmamouchi, E. Abdelkader, E. Marhuenda, and M. D. Herrera, Pharmacol Res., 54, 150 (2006).

Chemistry Division, School of Advanced Sciences, VIT University, Vellore, 632014, Tamil Nadu, India, fax: +91 0416 2243092, e-mail: jaya_saral@yahoo.com. Published in Khimiya Prirodnykh Soedinenii, No. 4, July-August, 2013, p. 668. Original article submitted April 16, 2012. 